\title{
Shame and Alienation in Kafka's The Metamorphosis
}

\author{
Karla S. Minar \\ Maranatha Christian University \\ karlasharin@gmail.com \\ Anton Sutandio \\ Maranatha Christian University \\ anton.sutandio@gmail.com
}

\begin{abstract}
This article explores Sartre's concept of shame and alienation in Kafka's The Metamorphosis through the portrayal of the protagonist. By focusing on the interpretation of the characteristics of Gregor Samsa through New Criticism approach, this article reveals that shame and alienation may occur when a person realizes that one is judged by others and sees oneself through the eyes of others. This way of looking at one's identity is problematic because it creates complexity within the existence of the self. Through his fantastical transformation into an insect, Gregor cannot help but see himself from his family's point of view. Instead of fighting for himself, he is made to believe that he deserves to be alienated. From the analysis of the protagonist, it is revealed that his being selfless and dutiful in a way trigger the shame and alienation that result in his submission to death.
\end{abstract}

Keywords: Alienation, Kafka, Sartre, Shame

\begin{abstract}
Abstrak
Artikel ini mengeksplorasi konsep perasaan malu dan pengasingan dari Sartre lewat analisis tokoh utama dari novella karya Franz Kafka, The Metamorphosis. Lewat interpretasi sang tokoh utama dengan menggunakan pendekatan New Criticism, artikel ini ingin menunjukkan bahwa perasaan malu dan pengasingan dapat terjadi ketika seseorang menggunakan penilaian negatif yang dilakukan oleh orang lain untuk menilai dirinya sendiri. Cara melibat identitas seseorang seperti ini menimbulkan masalah karena akan memunculkan permasalahan dalam eksistensi seseorang. Melalui transformasi fantastikal yang dialami oleh Gregor Samsa ketika dia berubah menjadi serangga besar, Gregor tidak dapat melihat dirinya sendiri tanpa melihat bagaimana keluarganya melihat dirinya. Dari hasil analisis karakteristik tokoh Gregor, terungkap bahwa sifatnya yang tidak egois dan berbakti secara tidak langsung memicu perasaan malu dan pengasingan yang pada akhimya membuat dia tidak lagi memiliki keinginan untuk hidup dan pasrah pada kematian.
\end{abstract}

Kata Kunci: Pengasingan, Kafka, Sartre, Perasaan Malu

\section{Introduction}

It is human nature to question everything around them. Back in the ancient times prior to Common Era, a number of great thinkers of the Western World such as Socrates, Plato, and Aristotle contemplated, from their own different perspectives, the meaning of the universe and all that exists in it. Their influence "...in subsequent philosophy and in literary theory has proved, for better or worse, the most enduring" (Petrovic, 2009:1), including on one philosophical movement, existentialism. 
Existentialism emerged in the $20^{\text {th }}$ century and was inspired by European philosophers Søren Kierkegaard and Friedrich Nietzsche. Neither Kierkegaard nor Nietzsche used the term existentialism in their work; however, they shared the notion that humans determine the meaning of their own existence through acts of will. Thus, according to Wrathall and Dreyfus (2016, 4), existentialism emphasizes on, “...human freedom and responsibility, and hold that the only goal consistent with that freedom and responsibility is to live authentically". "In simple terms, existential philosophers primarily emphasizes the meaning of human existence" (Acharya, 2011:1).

With the existence of human as an individual as its primary focus, existentialism deals with issues that revolve around particular matters that affect an individual's life. There are at least sixteen basic existentialist themes, and this article focuses one of them: alienation, which, “...emerges as natural consequences of an existential predicament" (Saleem, 2014:68). It can be simply explained as a situation when one is estranged from others.

The main method is library research that includes reading and understanding the primary text. This article applies New Criticism approach in which the writer focuses, “...mainly on the internal elements of the object like its language, diction, paradox, irony, ambiguity, tension, and rhyme scene. However, the total sum of these features is the structure of the work about which the critic is then able to pass judgment" (Taghizadeh, 2013:287). To make an objective and non-superficial analysis in the process of the analysis, the writer also consults some related references for support. The main element to analyze is the protagonist to reveal the concept of shame and alienation in the novel. The writer also focuses on the other elements because, “...the nature of every element in any given situation has no significance by itself, and in fact is determined by its relationship to all the other elements involved in that situation" (Hawkes, 2003:7).

Broadly speaking, alienation refers to "an individual's estrangement from the traditional community and others in general" (Davachi, 2009:11). French existentialist Jean-Paul Sartre has further expanded the concept of alienation. "According to Sartre, the seed of alienation is hidden in the experience of shame itself. In shame I experience a different self, the self of which I am ashamed does not exist prior to my encounter with the Other. It is the gaze of Other that confers this new self on me" (Sharma, 2015:61). The alienation he refers to is not only an estrangement from others but also from one's own self, and it is a consequence of shame.

Shame, in general, is "the feelings of sadness, embarrassment, and guilt that you have when you know that something you have done is wrong or stupid" (“Shame”), whereas shame according to Sartre $(1993,222)$ is explained as follows:

By the mere appearance of the other, I am put in the position of passing judgment on myself as an object, for it is as an object that I appear to the other... I could feel irritation, or anger before it as a bad trait of myself 
which gives to my expression an ugliness or baseness which I do not have, but I could not be touched to the quick. Shame is by nature recognition. I recognize that I am as the others see me. There is, however, no question of a comparison between what I am for myself and what I am for the other as if I found in myself, in the mode of being for itself, an equivalent of what I am for the other.

Thus, shame in the Sartrean term is a form of consciousness in an individual. To feel shame is to be aware of the presence of others. It is an acknowledgment that others exist and has the capability to look at an individual and judge him, which Sartre refers to as "the look" (Sartre, 1993:252).

Furthermore, Sartre believes that shame means to accept the fact that one is an object that the other looks at and forms opinions about (qtd. in Zahavi, 213). This acceptance is the result of a relationship between one and the other where one is concerned about the other's judgment (qtd. in Zahavi, 214). In other words, shame occurs if one cares about the opinions that the other forms about him. Moreover, whether the judgment of the other is positive or not, makes no difference (qtd. in Zahavi, 214). As Sartre writes, "Pure shame is not a feeling of being this or that guilty object but in general of being an object; that is, of recognizing myself in this degraded, fixed and dependent being which I am for the Other" (Sartre, 1993:288). Therefore, it is the way the other judges an individual as such that is shame-inducing.

Being judged this way and objectified by others is what alienates an individual. As Sartre puts it, "The alienation of myself is the fact of being-looked-at" (Sartre, 1993: 263). It is inevitable that others form an opinion about an individual based on what they see. However, what is seen is not exactly what an individual is as it is only part of the possibilities of the self (Sartre, 1993:267). The possibilities of the self here simply mean that an individual is a complex human being-an individual does not solely consist of a few characteristics. For example, one may be a cheerful and humorous individual, but it does not negate the possibility that one also has insecurities and unhappiness. When others only see one as cheerful and humorous, and one is aware of this judgment toward oneself as well as seeing oneself the way others see one, one experiences shame. This shame alienates one from both oneself and others, as one is seen by others as something that is not the self as a whole, yet one sees oneself the same way as others see one. Thus, to reiterate, shame is an individual's consciousness or awareness of the presence of others. It is when one acknowledges that one is an object of judgment by the other, and when one sees one's own self the way others see him. The feeling of shame leads to alienation or the estrangement from others and one's own self, as what others see is only a fragment of the possibilities of the self. In other words, the alienation is caused by an internal factor, as shame occurs from within an individual. This concept of alienation is the basis of the approach used to analyze the portrayal of the protagonist in The Metamorphosis. 
Franz Kafka is considered by many to be one of the most influential writers of the twentieth century. The surreal and enigmatic realm of his fictions and the clarity of his style make Kafka a major figure of modern literature. His name has lent itself to the English term “Kafkaesque,” which, “...has become part of the English vernacular... that described the alienation and exclusion of the individual in the face of modern bureaucracy" (Kaplan, 2014:115). His work has influenced many critically acclaimed writers, including Albert Camus, Gabriel García Márquez, and Haruki Murakami.

The majority of Kafka's works have the recurring theme of alienation, which is one of the main issues of existentialism. There are several concepts of alienation in philosophy and this article focuses on the one by Jean-Paul Sartre. Kafka is known to create a strong portrayal of characters, his typical protagonist is confused, hopeless, guilt-ridden, frustrated, and lacking in understanding of their surreal world. “Taken as a whole, Kafka's writing has an air of portent and melancholy" (Harwood 2007:15).

Metamorphosis is considered one of Kafka's best works, it is, “...perhaps the most enigmatic and challenging work of Kafka's oeuvre, on account of its extraordinary simultaneous realism and fantasy" (Valk, 2015: 57). There have been numerous articles and discussions on this work which signify its grandeur. "That Kafka's works have attracted so much interest from so many different perspectives and disciplines is evidence of the richness and subtle complexity of his writing and existential philos- ophy" (Rozuel, 2014: 26).

\section{The Metamorphosis}

The protagonist of The Metamorphosis is Gregor Samsa, a traveling salesman who is the only son as well as the breadwinner of the Samsa family. He mysteriously metamorphoses into an enormous insect, which leads to him being alienated from his family. However, he experiences not only alienation that is directly caused by his appearance, but also alienation as an indirect consequence of his characteristics. The author portrays him as someone who cares about others and is willing to do what others expect him to do. His characteristics provoke a feeling of shame, which eventually causes him to be estranged from his own family and himself. The following part is the analysis of his characteristics and how each induces shame that results in alienation.

\section{Selfless}

Gregor's first characteristic is selfless. The word selfless means "thinking more about the needs, happiness, etc. of other people than about your own" ("Selfless"). This characteristic is evident in the way he prioritizes his family's wellbeing over his own. At the beginning of the story, after finding himself metamorphosed into an insect, Gregor expresses his discontentment of his job as a traveling salesman, saying that it is "exhausting" and "much more irritating than doing actual business in the office" (Kafka,1995:89). Moreover, he describes the job as having the "trouble of constant traveling, of worrying about train connections, the bed, and irregular meals, 
casual acquaintances that are always new and never become intimate friends" (Kafka, 1995:89 -90). In other words, Gregor finds the job unpleasant as he has to travel constantly, which prevents him from having a healthy diet and, more importantly, from developing real friendships with other people. Therefore, he wants to quit his job. However, he suppresses his own desire to do so. Instead of quitting his job immediately, he continues working to pay his parents' debt to the chief whom Gregor works for. Gregor's thought when he wakes up as an insect is: "If I didn't have to hold my hand because of my parents I'd have given notice long ago... once I've saved enough money to pay back my parents' debt to him-that should take another five or six years-I'll do it without fail. I'll cut myself completely loose then" (Kafka, 1995:90). Evidently, Gregor plans to quit, but only after he has enough money to pay back his parents' debt. If he were not selfless, he could resign to free himself of the burdensome job. But what happens is that he stays committed to his work even though he is unhappy with it. $\mathrm{He}$ does not let his discontentment of his job get in the way of his family's needs, which indicates that his family is more important to him than his own self-in other words, he is selfless.

Besides trying to meet his family's needs, he wants to make his sister Grete happy. Gregor has a close relationship with Grete, as evident in the following quotation:

With his sister alone had he remained intimate, and it was a secret plan of his that she, who loved music, unlike bimself, and could play movingly on the violin, should be sent next year to study at the Conservatorium, despite the great expense that would entail, which must be made up in some other way. During his brief visits home the Conservatorium was often mentioned in the talks he had with his sister, but always merely a beautiful dream which could never come true, and his parents discouraged even these innocent references to it; yet Gregor had made up his mind firmly about it and meant to announce the fact with due solemnity on Christmas Day. (Kafka, 1995:111)

As can be seen from the quotation above, Gregor truly cares about his sister. He wants her dream of going to a music school to come true, and he is ready to deal with the expensive cost of the school admission and tuition. In order to make it happen, he works hard as a traveling salesman even though he is not content with his job. He suppresses his own desire to quit the job because if he does, he will not be able to make his sister's dream come true. Again, Gregor puts aside his own happiness in order to make others happy, which shows how selfless he is.

Furthermore, Gregor's selflessness is evident from his thoughts: he still cares about his family even though they abandon him. Initially, when they find out that Gregor has metamorphosed into an insect, his family, especially his sister, makes some efforts to take care of him even though Gregor's appearance horrifies them. According to Sokel (1956, 203), the species of vermin that Gregor changes into literally means dirty bug, which, “...denotes a slovenly and unclean individual". It may explain the family's reluctance to tend Gregor. However, as the story progresses, they care less and less about Gregor as his metamorphosis causes inconveniences to them. Eventually, his sister decides that they should get rid of 
him-a decision that Gregor himself "held to even more strongly than his sister" (Kafka, 1995:135). Gregor's thought of her sister's decision shows his selflessness; he is willing to be removed from the family so that they do not have to go through the troubles of living with a huge insect.

However, Gregor does not leave, which contradicts his own thought of leaving his family. This contradiction prevents him from taking actions of selflessness, which makes the characteristic only evident in his intentions or thoughts, but not in his actions. This contradiction can be explained as follows: On one hand, he is more than willing to be removed from the family so that they will no longer have to deal with the inconveniences that his metamorphosis causes. On the other hand, he cannot leave the house because his condition as an insect prevents him from leaving. The narrative states that he does not eat for days as he loses his appetite and at some point gets injured from being thrown objects, which implies that he does not have the physical strength to crawl out of his house and disappear. Besides, he stays because he wants to remind himself that he is human. All the belongings in his room are a reminder that he is human. In the middle of the story, his family decides to clean Gregor's room out of all the furniture and other belongings, as they do not see his need of them now that he is no longer human. Initially, Gregor accepts their plan, but then he changes his mind, as quoted: "Did he really want his warm room, so comfortably fitted with old family furniture, to be turned into a naked den in which he would certainly be able to crawl unhampered in all directions but at the price of shedding simultaneously all the recollection of his human background?” (Kafka, 1995:118). And finally, he thinks that "nothing should be taken out of his room; everything must stay as it was" (Kafka, 1995:118). His wish that his room should stay the same indicates that he, according to Nabokov $(1982,17)$, “...clings to human memories, human experience", as a reminder of his human identity. Consequently, he cannot leave his family because of his condition-physically trapped in an insect body and mentally attached to his human identity-although he wants his family to live normally without the troubles of taking care of a giant insect. According to Powell $(2008,130)$, “...by playing off this tension between human and non-human, between what is 'the self' and what is 'not the self,' Kafka is able to explore the ontology of otherness that clarifies the space between self and other". In the context of Gregor, he seems to stick in the space between self and other as he still tries to figure out what to do with his transformation.

Thus, at this point, Gregor's selflessness is only evident in his intentions or thoughts, but not in his actions, because of the aforementioned contradiction. Moreover, considering how frightening his physical form is, it is difficult for him to do something for his family without startling them. In other words, he becomes passive in showing his selflessness compared to the time when he tries to go back to work in order to fulfill his family's needs. Nevertheless, he is still selfless because in his last moments Gregor still loves his family, 
as can be seen from the following quotation:

Soon be made the discovery that he was unable to stir a limb. This did not surprise him, rather it seemed unnatural that he should ever actually have been able to move on these feeble little legs. Otherwise, he felt relatively comfortable. True, his whole body was aching, but it seemed that the pain was gradually growing less and would finally pass away. The rotting apple in bis back and the inflamed area around it, all covered with soft dust, already hardly troubled him. He thought of his family with tenderness and love. The decision that he must disappear was one that he held to even more strongly than his sister if that were possible. In this state of vacant and peaceful meditation, he remained until the tower clock struck three in the morning. The first broadening of light in the world outside the window entered his consciousness once more. Then his head sank to the floor of its own accord and from his nostrils came the last flicker of his breath. (Kafka, 1995:135)

The way he peacefully succumbs to death can be interpreted as his last effort of making his family's life better. He accepts that death is the only way for him to disappear, which is what the family wants. Thus, his death emphasizes his selflessness.

As can be seen from the elaboration above, Gregor is selfless, which means that he always puts his family before himself; he cares more about their needs and happiness than his own. It is natural for him to be concerned with his family, especially since his family depends on him. Realizing that his family depends on him implies that he has the awareness that he is an object of the judgment of his family. The awareness that others judge an individual is what Sartre's concept of shame is about. Shame causes one to be alienated from others because what others see in an individual is only a fragment of the possibilities of the self. Furthermore, shame also alienates one from one's own self as one sees oneself as what others see him.

In Gregor's case, he experiences alienation before and after his metamorphosis. It is implied that since the time before his metamorphosis, Gregor has been selfless; yet, his family takes his selflessness for granted, as can be seen in the following quotation:

\section{... He had set to work with unusual ardor and almost overnight had become a commercial travel- er instead of a little clerk, with of course much greater chances of getting money, and his success was immediately translated into good round coin which he could lay on the table for his amazed and happy family. These had been fine times, and they had never recurred, at least not with the same sense of glory, although later on Gregor had earned so much money that he was able to meet the expenses of the whole housebold and did so. They had simply got used to it, both the family and Gregor; the money was gratefully accepted and gladly given, but there was no special uprush of warm feeling. (Kafka, 1995:110-111)}

His family is so used to Gregor being a successful breadwinner that they fail to consider the possibilities of Gregor as an individual-the possibilities of Gregor feeling unhappy with his life, or feeling lonely because he has no friends, and so on. This explains why the family members do not really concern about him and do not seem to be able to see him as a complex human being with his own needs. As a result, Gregor is alienated from both his family and himself. After his metamorphosis, Gregor experiences another alienation that is caused by his physical form. His family sees him as a frightening, troublesome creature, as indicated by how they are frightened with 
his presence and how they eventually decide to get rid of him. Gregor, who experiences shame, also sees himself that way. Both he and his family unknowingly deny the possibilities of Gregor as an individual, which causes him to be alienated.

\section{Dutiful}

Gregor's second characteristic is dutiful. The definition of dutiful is "doing everything that you are expected to do; willing to obey and to show respect". His dutifulness is evident in his action of keeping his job as a traveling salesman in order to pay his parents' debt. His father is old and unemployed; therefore, as the only son and breadwinner of the family, he is aware of his family's expectation, which is for him to provide for the family and to pay the debt.

As mentioned previously, Gregor finds the job tiresome; he expresses his discontentment at the beginning of the story. However, he continues to be a dedicated worker as shown by the way he insists on going to work despite his metamorphosis. His immediate thought when he wakes up as an insect is, "I'd better get up since my train goes at five" (Kafka, 1995:90). As Antin (1995, 269) argues that, “...Gregor confronts his physical transformation from the point of view of the wretched human being he has always been-the dutiful son...." Besides, he never questions the mystery of his metamorphosis in the first place. It seems that his physical form does not concern him; what matters is that he should go to work. Clearly, his mind is set on doing his duty, which shows how dutiful he is.

When the chief clerk comes into his apartment to inquire him of his tardiness, Gregor's mother defends him as quoted: “'He's not well,' said his mother to the visitor, while his father was still speaking through the door, 'he's not well, sir, believe me. What else would make him miss a train! The boy thinks nothing but his work"' (Kafka, 1995:95). In other words, Gregor, as seen by another character, which in this case is his mother, is such a dedicated worker that the only explanation for his tardiness must be an illness. Gregor's dutifulness is further revealed through his own speech to the chief clerk while trying to convince him not to fire him as quoted: 'You see, sir, I'm not obstinate, and I'm willing to work; traveling is a hard life, but I couldn't live without it... I'm loyally bound to the chief, you know that very well. Besides, I have to provide for my parents and my sister" (Kafka, 1995:101). Moreover, as mentioned in the narrator's direct comment, back when Gregor's father's business goes bankrupt, Gregor's only desire is "to do his utmost to help the family to forget as soon as possible the catastrophe that had overwhelmed the business and thrown them all into a state of complete despair"; therefore, he "had set to work with unusual ardor and almost overnight had become a commercial traveler" (Kafka, 1995:111). It proves that he is willing to do what he is expected to do as the son and the breadwinner of the family-in other words, he is dutiful.

When one is dutiful, it is natural that one has the awareness of what others expect from oneself and of what others see one as. Since it is 
in Gregor's nature to be dutiful, it means that he has the aforementioned awareness. Again, this awareness is known as shame in Sartrean term. Shame is when one sees one's own self the way others perceive him. When he is physically transformed, Gregor cannot fulfill his duty as the breadwinner of the family anymore; besides, his condition makes his family's life difficult. Therefore, his family sees him as a burden, as shown by the fact that they want to get rid of him. As Gregor experiences shame, he sees himself the way his family sees him, a burden. This alienates him because he is denied from the possibilities of himself as an individual who constantly puts others before himself and does everything he is expected to do even though he has his own needs.

Based on the analysis above, Kafka portrays Gregor as a character who accepts what others perceive of him. The perceptions of others about himself affect his relationship with other people as well as his actions. In relation to Sartre's theory, Gregor's portrayal illustrates how an individual experience the feeling of shame that eventually results in alienation. Shame causes Gregor to see himself the way others see him, which leads to alienation because what others see is only a part of the possibilities of the self.

\section{Conclusion}

We follow the story of Gregor Samsa in The Metamorphosis, which begins with Gregor waking up as a giant insect. He is a static character with selflessness and dutifulness as his major traits. Instead of questioning the mystery of his physical transformation, he desperately tries to get back to work so that he can provide for his family. He prioritizes his family's well-being than his own as he is a selfless person. Besides being selfless, he is also a dutiful son and breadwinner; he tries his best to meet his family's needs despite his discontentment of his job. Upon discovering Gregor's metamorphosis, his family isolates him because of his frightening physical form; they isolate him in his room as they cannot bear the sight of him. Thus, Gregor experiences alienation that is by his physical appearance. However, he also experiences a different kind of alienation, one that is actually a non-direct consequence of his characteristics, and it is not the only estrangement from others but also from his own self. His selflessness and dutifulness come with an awareness that he is an object of judgment by his family, and make him sees himself the way his family sees him, which in Sartrean term is known as shame. The metamorphosis causes Gregor's family to see him as a worthless, horrifying creature. Moreover, prior to Gregor's metamorphosis, they only see him as the breadwinner of the family. The way they always see him denies the possibilities of looking at Gregor as a complex individual, which then alienates Gregor.

Kafka's portrayal of Gregor illustrates how alienation comes from within an individual. The Metamorphosis shows how the protagonist is being estranged from the people around them because of the outer part of the individual, which is his physical appearance. However, seen from Sar- 
tre's concept of alienation, the source of alienation is actually the inner part of the individual himself. His characteristics induce shame, which means Gregor realizes that he is judged by others and see himself the way others see him. The feeling of shame eventually leads to alienation, which affects an individual in determining one's own existence. As depicted in the novella, alienation overwhelms Gregor without him realizing it. Being estranged from others, Gregor gradually loses his will to live. Thus, it implies that humans have a subconscious need for connecting with others and that the existence of others has an impact on an individual's existence.

\section{References}

Acharya, Vinod. 2011. "Nietzsche's MetaExistentialism". Ph.D. Diss., Rice University.

Antin, David. 1995. Radical Coherency. Chicago: The University of Chicago Press.

Davachi, Azadeh. 2010. "Existential Absurdity and Alienation in Kafka's The Metamorphosis and Hedayat's The Blind Owl". MA the.,Universiti Putra Malaysia.

“Dutiful." OALD Online. http:// www.oxfordlearnersdictionaries.com/ definition/english/dutiful?q=dutiful (27 June 2017)

Harwood, Catherine. 2007. Franz Kafka's Literature and the Law. w w w.rese a r chgate.net/ p $\begin{array}{lllllll} & \mathrm{b} & \mathrm{b} & \mathrm{l} & \mathrm{i} & \mathrm{c} & \mathrm{a}\end{array}$ tion/242136262_FRANZ_KAFKA\% 27S_LITERATURE_AND_THE_LA W
Hawkes, Terence. 2007. Structuralism and Semiotics. London: Routledge.

Kafka, Franz. 1995. The Complete Stories. Translated by Willa and Edwin Muir. Prague: Schocken Books Inc.

Kaplan, Robert M. 2014. “Joseph K. Claims Compensation: Franz Kafka's Legal Writings". Advances in Historical Studies3:115121.

Khairunnisa, Anindya Firda. 2016. "Malformation and Isolation: Critique to Jewish Orthodoxy Found in Franz Kafka's The Metamorphosis”. BA Project, Universitas Gajah Mada.

Nabokov, Vladimir. 1982. "Lectures on Literature". http://victorian.fortunecity.com/

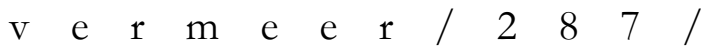
nabokov_s_metamorphosis.htm

Petrovic, Lena. 2009. "Plato's Legacy: A Revision".Facta Universitatis, Linguistics and Literature1 (7): 1-17.

Powell, Matthew T. 2008. "Bestial Representations of Otherness: Kafka's Animal Stories". Journal of Modern Literature 32(1): 129-142.

Rozuel, Cécile. 2014. "Otherness in Self and Organizations: Kafka's The Metamorphosis to Stir Moral Reflection". Research in Ethical Issues in Organizations 11: 25-50.

Saleem, Abdul. 2014. "Theme of Alienation in Modern Literature". European Journal of English Language and Literature Studies 2(3): 67-76.

Sartre, Jean-Paul. 1993. Being and Nothingness. Trans. Hazel E. Barnes. New York: The Philosophical Library.

"Shame." Oxford Learner's Dictionary. OALD $O n l i n e . \quad \mathrm{h} t \mathrm{t} p: / /$ www.oxfordlearnersdictionaries.com/ definition/english/shame_1?q=shame 
(10 June 2017)

Sharma, Pallavi. 2015. "Problem of the Other in Jean Paul Sartre's Existential Phenomenology". Ph.D. Diss., Indian Institute of Technology.

"Selfless." Oxford Learner's Dictionary. OALD O n l i n e. h t $\mathrm{t} \mathrm{p}:$ / / www.oxfordlearnersdictionaries.com/ definition/english/selfless?q=selfless (25 June 2017)

Sokel, Walter H.1956. “Kafka's 'Metamorphosis': Rebellion and Punishment". Monatshefte48(4): 203-214.

Taghizadeh, Ali. 2013. "A Theory of Literary Structuralism (in Henry James)". Theo$r y$ and Practice in Language Studies 3(2): 285-292.

Valk, Francina Cornelia. 2015. "Exclusion and Renewal: Identity and Jewishness in Franz Kafka's "The Metamorphosis" and David Vogel's Married Life". Ph.D. Diss., Universiteit Leiden.

Wrathall, Mark A. \& Dreyfus, Hubert L. 2016. A Brief Introduction to Phenomenology and Existentialism. Research $\mathrm{G}$ a $\mathrm{t}$ e , d o $\mathrm{i}$ : 10.1002/9780470996508.ch1

Zahavi, Dan. 2010. "Shame and the Exposed Self'. In Ed. J. Webber, Reading Sartre: On Phenomenology and Existentialism, edited by J. Webber. London: Routledge. 